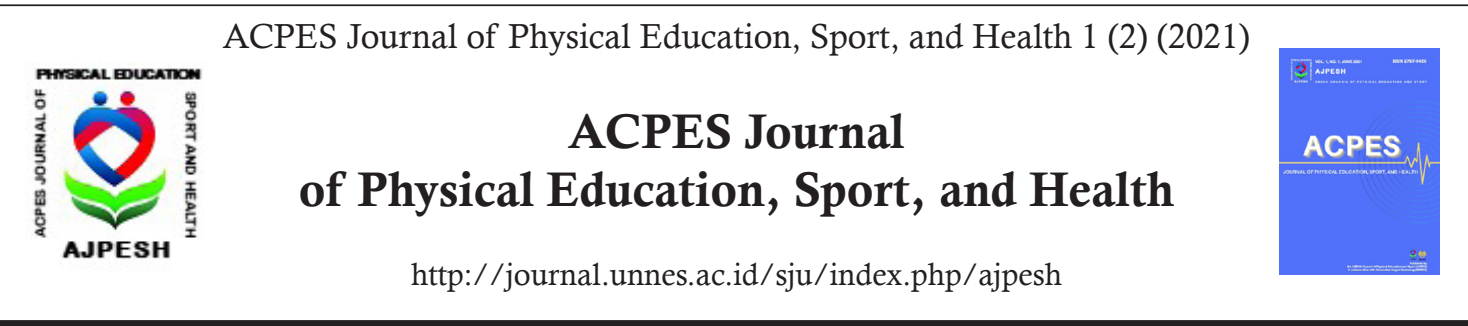

\title{
The Effects of Health Promotion Literacy Program on Knowledge and Health Behaviors of National Health Recommendations among Middle School Students
}

\author{
Kanyarat Khamwichai ${ }^{\circledR}$, Natchapat Yurahan ${ }^{2}$, Sununta Srisiri ${ }^{3}$, Pimpa Moungsirithum $^{3}$ \\ ${ }^{1}$ The Demonstration School of Phetchaburi Rajabhat University, Thailand \\ ${ }^{2}$ Bansuan Jananusorn School, Thailand \\ ${ }^{3}$ Faculty of Physical Education, Srinakharinwirot University, Thailand
}

DOI: https://doi.org/10.15294/ajpesh.v1i2.49950

\begin{tabular}{l} 
Article Info \\
\hline Article History \\
Submitted 2021-09-15 \\
Revised 2021-10-29 \\
Accepted 2021-12-10 \\
\hline Keywords \\
Health Literacy; health \\
behaviors; National \\
Health Recommendations
\end{tabular}

\begin{abstract}
This study was examined the effect of health promotion literacy program on knowledge and health behaviors of Ten National Health Recommendations among middle school students. Classroom action research was implemented among grade 8 students at middle school students selected purposively. Two comparable schools were assigned to the online Health Promotion Literacy Program for 3 weeks. The instruments employed in the study consisted of Health Promotion Literacy Program, questionnaire on knowledge and health behaviors, and user satisfaction survey. It revealed there was a significant difference in the learning achievement of health literacy and health behaviors of each school those who were participated in Health Promotion Literacy Program who performed posttest better than pretest the programme $(\mathrm{t} 1=24.26, \mathrm{P} 1=0.000, \mathrm{t} 2=26.33, \mathrm{P} 2=0.000)$. It revealed there was an insignificant difference in the learning achievement of health literacy and health behaviors of both affiliations that it is shown that students who come from different schools totally have similar knowledge, perceptions, and behaviors $(\mathrm{t}=1.22, \mathrm{P}=0.848)$. The students who participated in health promotion literacy program had satisfaction at good level ( $\mathrm{x} \square=4.39$ ). From the study, health literacy promotion program on health behaviors according to the National Health Recommendations can positively affects student learning outcomes.
\end{abstract}

\section{INTRODUCTION}

Currently, the youth people changed their lifestyles as the information technology has been developed and situation of the COVID-19 has harshly pandemics. These events have cause health crisis. For example, students have accumulated stress from studying because of a competitive examination, they are spending time for screen all day and unstable revenue of family. According to the examples, the youth people will need to maintain one's health and decrease risk of health behaviors. Furthermore, they are less immature of self-learning systematization can bring communicable diseases or get hurt from an accident. Therefore, it is essential that young people have correctly receive news hygienic information among digital age because information can be fake news that would be inconsistent with principle. News hygienic information have enormously several source and it is easily reach. If young people do not have a health literacy, they will become victim of demagogue. The consequence may be destroyed involuntary health. Health Promotion Literacy Program concept is the key to human resource development. Health Literacy is cognitive processes and social skills lead to motivation. It 
makes level individual ability to access, understand, and use information excellently. Health Literacy is promoted and maintain always good health (Health Education Division, Department of Health Service Support, 2019; Kaeodumkoeng, 2018; Silva \& Santos, 2021). The Ministry of Health has the 12th National Health Development plan (2017-2021). This plan gives precedence with Health Literacy in the first strategy. First, immediacy promote approach strategy health of Thai people. Strategy achievement increases level of health literacy of everyone to a very good level. Second, Thai people have better health behaviors such as people more exercises, people more consume vegetable, The prevalence of smoke and drink decreasingly and Thai people have sickness and death rate decreasingly (The Board of Directors for the Preparation of the National Health Development Plan, No. 12, Ministry of Health, 2016). Finally, supporting and promotion throughout one's life learn to quality of life. So, it is important that young people receive encouragement and supports Health Promotion Literacy Program. They will be developed the ability to find, understand, and use information and services to inform health-related decisions and actions for themselves and others.

\title{
OBJECTIVES
}

This study was examined health literacy of health behaviors according to the National Health Recommendations of middle school students in Ministry of Higher Education, Science, Research, and Innovation affiliation. This study was examined health literacy of health behaviors according to the National Health Recommendations of middle school students in Office of the Basic Education Commission affiliation. This study was examined comparison the effects of the health literacy promotion program on health behaviors according to the National Health Recommendations of both affiliations.

\section{CONCEPTUAL FRAMEWORK}

Health Promotion Literacy Program

\author{
1. skills find and access to health services \\ information. \\ (Lecture / Search /Investigation)
}

\section{2. skills enhanced learning understand and services health information. \\ (Lecture / Contemplation)}

\section{3. skills respond and question health information. \\ (Lecture / Partner)}

\section{4. skills decide in order to choose practice.}

(Repetition/Gamification)

5. skills adjust health behavior.

(Set targets/ Partner)

6. skills go out to present and notify health information for society.

(Lecture / Partner)

\section{METHODS}

This study was pre-quasi-experimental research which have two groups (pre - posttest design).

\section{Setting and Participants}

This study was conducted in a middle school of Demonstration School of Phetchaburi Rajabhat Uni- 
versity and Bansuan Jananusorn School. The middle school students were invited to participate in this study by purposive sampling. The experiment was conducted in the online learning. Prior to enrollment, eligible students and their parents were informed that they could freely access, participate in or withdrawal from the research at any time. sixty students who were in grade 8 agreed to participate in the study. The students of Phetchaburi Rajabhat University Demonstration School $(n=30)$ and the students of Bansuan Jananusorn School $(\mathrm{n}=30)$ under teachers' and researchers' supervision. Under teachers' supervision, students initiated and conducted activity and engaged in activities for health promotion literacy program of to the National Health Recommendations throughout 3 weeks, from June 21 to July 9, 2021.

\section{Instrument}

The instruments were (1) Health Promotion Literacy Program of Ten National Health Recommendations have 6 plans, (2) questionnaire on knowledge and health behaviors, (3) user Satisfaction Survey. There are detail the follows:

(1) the content of health promotion literacy program of National Health Recommendations consisted of 1) information about skills find and access to health services information. ; 2) information about skills enhanced learning understand and services health information.; 3) information about skills respond and question health information.; 4) information about skills decide in order to choose practice.; 5) information about skills adjust health behavior. and 6) information about skills go out to present and notify health information for society. These instruments were sent to 3 experts in order to assess the suitability found that IOC was 0.76-1.00.

(2) the questionnaire on knowledge and health behaviors used from Academic and Quality Development of Health Education Division, Division of Health Education, 2020. It was a standard and examined reliability.

(3) researcher used Satisfaction Survey of Sumeth Naorungrote' research Published in Innovative Distance Learning Electronic Journal.

\section{Research Procedure}

Prior to the experiment, the researcher requested permission from the students' parents of the experimental and comparison groups. When permission was granted, the researcher will explain the research project and schedule a research period. Then, the researcher met students to explain the research project via online and pre-test data were collected with assessment forms of health literacy and behaviors of students according to the National Health Recommendations via online of both experimental groups. The research lasted for a total of 3 weeks as follows:

Week 1: To conduct a program in order to promote health literacy according to the National Health Recommendations once a week and three hours each time via online. In the class, reduce the study time, increase the knowledge and guidance time. Details are as follows:

Activity 1: To develop information retrieval skills and health services accessibility. The purpose is that students are enabled to search, check, access, and receive health-related services from reliable sources by presenting as a lecture, and students can practice searching for information and checking health information.

Activity 2: To develop comprehensive skill of information and health services. The purpose is that students are enabled to understand the content and find the main idea of the content about health clearly and accurately by presenting as a lecture, and students can practice comprehensive reading of health information.

Activity 3: To develop interrogative skills in order to increase understanding of health. The purpose is that students can respond to questions, get the health information they need, and discuss about health information for mutual understanding by presenting as a lecture, and students pair up to present their work.

Week 2: To conduct a program that promote health literacy according to the

National Health Recommendations for once a week and 3 hours each time via online in Moderate Class More Knowledge class and guidance class. The details are as follows:

Activity 4 To develop decision-making skills for health practice. The purpose is that students can analyze good or bad results of self-care and compare health information from multiple sources by using gamification model and reviewing themselves. (Kapp, 2012)

Activity 5 To develop health behavior modification skill. The purpose is that students are enabled to plan health behavior modification and know how to modify health behavior in order to meet 
the appropriate goals by using a goal setting model, and students pair up and present their work (Park et al., 2017).

Activity 6 To develop health information presentation skill for society. The purpose is that students can share their experiences of their health care and present health care approaches that benefit the community by presenting as a lecture, and students pair up to present their work.

Week 3: Post-test data were collected by using health literacy and health behavior assessment forms of students according to the National Health Recommendations of the two experimental groups and ask and answer questions that students have doubts by spending an hour in Moderate Class More Knowledge class.

\section{Statistical Analysis}

Frequency and percentage were calculated to describe the general characteristics of middle school students. Mean and standard deviations were calculated to determine the health literacy cognitive test of the students. The paired t-test and independent $t$-test were used to compare statistical differences at $p=0.05$ of mean score of knowledge about health literacy and health behaviors of the students that were exposed to health promotion literacy program of National Health Recommendations.

\section{RESULTS AND DISCUSION}

The results were found that:

Experimental : The students of Phetchaburi Rajabhat University Demonstration School $(n=30)$. General information: The students are 14 male $(46.67 \%)$ and 16 female $(53.33 \%)$ who aged 13-15 years. Most of them have 24 students (80\%) receive a grade point average of 3.01-4.00 and minority 6 students $(20 \%)$ receive a grade point average of 2.01-3.00.

Table 1. Comparison Pre-Posttest score of health literacy program of National Health Recommendations of Phetchaburi Rajabhat University Demonstration School students.

\begin{tabular}{|c|c|c|c|c|c|c|c|c|}
\hline \multirow{2}{*}{ Evaluation details } & \multicolumn{2}{|c|}{ pretest } & \multirow{2}{*}{ level } & \multicolumn{2}{|c|}{ posttest } & \multirow{2}{*}{ level } & \multirow{2}{*}{$\mathrm{t}$} & \multirow{2}{*}{ p-value } \\
\hline & & S.D. & & & S.D. & & & \\
\hline 1. Health Literacy knowledge. & 80.66 & 0.91 & Fair & 101.80 & 0.76 & Excellence & 25.16 & .000 \\
\hline $\begin{array}{l}1.1 \text { skills find and access to health services in- } \\
\text { formation. }\end{array}$ & 14.77 & 0.98 & Good & 17.03 & 0.75 & Excellence & 6.77 & .000 \\
\hline $\begin{array}{l}1.2 \text { skills enhanced learning understand and ser- } \\
\text { vices health information. }\end{array}$ & 14.90 & 0.84 & Good & 17.27 & 0.65 & Excellence & 8.04 & .000 \\
\hline $\begin{array}{l}1.3 \text { skills respond and question health informa- } \\
\text { tion. }\end{array}$ & 14.63 & 0.85 & Good & 17.10 & 0.71 & Excellence & 8.04 & .000 \\
\hline 1.4 skills decide in order to choose practice. & 13.53 & 0.77 & Fair & 17.40 & 0.62 & Excellence & 10.42 & .000 \\
\hline 1.5 skills adjust health behavior. & 11.20 & 0.76 & Poor & 16.27 & 0.95 & Good & 15.90 & .000 \\
\hline $\begin{array}{l}1.6 \text { skills go out to present and notify health in- } \\
\text { formation for society. }\end{array}$ & 11.63 & 0.76 & Poor & 16.73 & 0.81 & Good & 15.53 & .000 \\
\hline 2. Health Behaviors. & 45.23 & 1.29 & Fair & 64.47 & 0.99 & Excellence & 23.35 & .000 \\
\hline
\end{tabular}

* Significant statistical level at 0.05

In Table 1, the result showed a significant difference in the health literacy program of National Health Recommendations of Phetchaburi Rajabhat University Demonstration School students. This implied that students who participated in Health Promotion Literacy Program who performed posttest better than pretest of both topics $(\mathrm{t} 1=25.16, \mathrm{P}=.000, \mathrm{t} 2=23.35, \mathrm{P}=.000)$. When considering each sub-topic, the results show that the students who completed of health promotion literacy program had higher average test score than those who did not receive the programme. $(\mathrm{t} 1.1=6.77, \mathrm{P}=.000, \mathrm{t} 1.2=8.04, \mathrm{P}=.000, \mathrm{t} 1.3=8.04$, $\mathrm{P}=.000, \mathrm{t} 1.4=10.42, \mathrm{P}=.000, \mathrm{t} 1.5=15.90, \mathrm{P}=.000, \mathrm{t} 1.6=15.53, \mathrm{P}=.000)$. The mean score among students participating the programme was higher than formerly.

Experimental : The students of Bansuan Jananusorn School $(\mathrm{n}=30)$. General information: The students are 11 male (36.67\%) and 19 female (63.33\%) who aged 13-15 years. Most of them have 21 students (70\%) receive a grade point average of 3.01-4.00 and minority 9 students $(30 \%)$ receive a grade point average of $2.01-3.00$. 
Table 2. Comparison Pre-Posttest score of health literacy program of National Health Recommendations of Bansuan Jananusorn School students.

\begin{tabular}{|c|c|c|c|c|c|c|c|c|}
\hline Evaluation details & pretest & & level & posttest & & level & $\mathrm{t}$ & $\mathrm{p}$-value \\
\hline & & S.D. & & & S.D. & & & \\
\hline 1. Health Literacy knowledge. & 78.73 & 0.75 & Fair & 106.23 & 0.66 & Excellence & 34.50 & .000 \\
\hline $\begin{array}{l}1.1 \text { skills find and access to health services in- } \\
\text { formation. }\end{array}$ & 14.20 & 0.65 & Good & 17.63 & 0.68 & Excellence & 12.45 & .000 \\
\hline $\begin{array}{l}1.2 \text { skills enhanced learning understand and ser- } \\
\text { vices health information. }\end{array}$ & 14.10 & 0.74 & Good & 18.10 & 0.55 & Excellence & 13.09 & .000 \\
\hline $\begin{array}{l}1.3 \text { skills respond and question health informa- } \\
\text { tion. }\end{array}$ & 14.07 & 0.66 & Good & 17.70 & 0.64 & Excellence & 12.86 & .000 \\
\hline 1.4 skills decide in order to choose practice. & 14.10 & 0.69 & Good & 18.37 & 0.54 & Excellence & 14.73 & .000 \\
\hline 1.5 skills adjust health behavior. & 11.23 & 0.71 & Poor & 17.03 & 0.70 & Excellence & 15.08 & .000 \\
\hline $\begin{array}{l}1.6 \text { skills go out to present and notify health in- } \\
\text { formation for society. }\end{array}$ & 11.03 & 0.58 & Poor & 17.40 & 0.78 & Excellence & 18.38 & .000 \\
\hline 2. Health Behaviors. & 51.63 & 1.37 & Fair & 66.90 & 0.79 & Excellence & 18.16 & .000 \\
\hline
\end{tabular}

* Significant statistical level at 0.05

In Table 2, the result showed a significant difference in the health literacy program of National Health Recommendations of Bansuan Jananusorn School students. This implied that students who participated in Health Promotion Literacy Program who performed posttest better than pretest of both topics $(\mathrm{t} 1=34.50, \mathrm{P}=.000, \mathrm{t} 2=18.16, \mathrm{P}=.000)$. When considering each sub-topic, the results show that the students who completed of health promotion literacy program had higher average test score than those who did not receive the programme. $(\mathrm{t} 1.1=12.45, \mathrm{P}=.000, \mathrm{t} 1.2=13.09, \mathrm{P}=.000, \mathrm{t} 1.3=12.86, \mathrm{P}=.000, \mathrm{t} 1.4=14.73, \mathrm{P}=.000$, $\mathrm{t} 1.5=15.08, \mathrm{P}=.000, \mathrm{t} 1.6=18.38, \mathrm{P}=.000)$. The mean score among students participating the programme was higher than formerly.

Table 3. Comparison Pretest score of health literacy program of National Health Recommendations of both affiliations.

\begin{tabular}{|c|c|c|c|c|c|c|c|c|}
\hline \multirow{2}{*}{ Evaluation details } & \multicolumn{2}{|l|}{ Gr1 } & \multirow{2}{*}{ level } & \multicolumn{2}{|l|}{ Gr2 } & \multirow{2}{*}{ level } & \multirow{2}{*}{$\mathrm{t}$} & \multirow{2}{*}{ p-value } \\
\hline & & S.D. & & & S.D. & & & \\
\hline 1. Health Literacy knowledge. & 80.66 & 0.91 & Fair & 78.73 & 0.75 & Fair & 0.90 & .476 \\
\hline 1.1 skills find and access to health services information. & 14.77 & 0.98 & Good & 14.20 & 0.65 & Good & 1.05 & .360 \\
\hline $\begin{array}{l}1.2 \text { skills enhanced learning understand and services } \\
\text { health information. }\end{array}$ & 14.90 & 0.84 & Good & 14.10 & 0.74 & Good & 1.61 & .208 \\
\hline 1.3 skills respond and question health information. & 14.63 & 0.85 & Good & 14.07 & 0.66 & Good & 0.72 & .495 \\
\hline 1.4 skills decide in order to choose practice. & 13.53 & 0.77 & Fair & 14.10 & 0.69 & Good & 0.90 & .552 \\
\hline 1.5 skills adjust health behavior. & 11.20 & 0.76 & Poor & 11.23 & 0.71 & Poor & 0.22 & .831 \\
\hline $\begin{array}{l}1.6 \text { skills go out to present and notify health information } \\
\text { for society. }\end{array}$ & 11.63 & 0.76 & Poor & 11.03 & 0.58 & Poor & 0.90 & .412 \\
\hline 2. Health Behaviors. & 45.23 & 1.29 & Fair & 51.63 & 1.37 & Fair & 1.90 & .218 \\
\hline
\end{tabular}

* Significant statistical level at 0.05

In Table 3, the result showed an insignificant difference in the health literacy program of National Health Recommendations of Phetchaburi Rajabhat University Demonstration School students and Bansuan Jananusorn School students. This implied that students who come from each school those who did not receive the programme those who were similarly achievement. This described that the students have health literacy and health behaviors of National Health Recommendations those who did not differ the programme. $(\mathrm{t} 1=0.90, \mathrm{P}=.476, \mathrm{t} 1.1=1.05, \mathrm{P}=.360, \mathrm{t} 1.2=1.61, \mathrm{P}=.208, \mathrm{t} 1.3=0.72$, $\mathrm{P}=.495, \mathrm{t} 1.4=0.90, \mathrm{P}=.552, \mathrm{t} 1.5=0.22, \mathrm{P}=.831, \mathrm{t} 1.6=0.90, \mathrm{P}=.412, \mathrm{t} 2=1.90, \mathrm{P}=.218)$. 
Table 4. Comparison Posttest score of health literacy program of National Health Recommendations of both affiliations.

\begin{tabular}{|c|c|c|c|c|c|c|c|c|}
\hline Evaluation details & Gr1 & & level & Gr2 & & level & $\mathrm{t}$ & $\mathrm{p}$-value \\
\hline & & S.D. & & & S.D. & & & \\
\hline 1. Health Literacy knowledge. & 101.80 & 0.76 & Excellence & 106.23 & 0.66 & Excellence & 1.12 & .448 \\
\hline $\begin{array}{l}1.1 \text { skills find and access to health services } \\
\text { information. }\end{array}$ & 17.03 & 0.75 & Excellence & 17.63 & 0.68 & Excellence & 1.06 & .758 \\
\hline $\begin{array}{l}1.2 \text { skills enhanced learning understand and } \\
\text { services health information. }\end{array}$ & 17.27 & 0.65 & Excellence & 18.10 & 0.55 & Excellence & 1.33 & .286 \\
\hline $\begin{array}{l}1.3 \text { skills respond and question health in- } \\
\text { formation. }\end{array}$ & 17.10 & 0.71 & Excellence & 17.70 & 0.64 & Excellence & 0.97 & .537 \\
\hline 1.4 skills decide in order to choose practice. & 17.40 & 0.62 & Excellence & 18.37 & 0.54 & Excellence & 1.65 & .211 \\
\hline 1.5 skills adjust health behavior. & 16.27 & 0.95 & Good & 17.03 & 0.70 & Excellence & 0.89 & .457 \\
\hline $\begin{array}{l}1.6 \text { skills go out to present and notify health } \\
\text { information for society. }\end{array}$ & 16.73 & 0.81 & Good & 17.40 & 0.78 & Excellence & 0.81 & .438 \\
\hline 2. Health Behaviors. & 64.47 & 0.99 & Excellence & 66.90 & 0.79 & Excellence & 0.94 & .553 \\
\hline
\end{tabular}

${ }^{*}$ Significant statistical level at 0.05

In Table 4, the result showed an insignificant difference in the health literacy program of National Health Recommendations of Phetchaburi Rajabhat University Demonstration School students and Bansuan Jananusorn School students. This implied that students who come from each school those who participated in health promotion literacy program those who were similarly achievement. This described that the students have health literacy and health behaviors of National Health Recommendations those who did not differ the programme. $(\mathrm{t} 1=1.12, \mathrm{P}=.448, \mathrm{t} 1.1=1.06, \mathrm{P}=.758, \mathrm{t} 1.2=1.33$, $\mathrm{P}=.286, \mathrm{t} 1.3=0.97, \mathrm{P}=.537, \mathrm{t} 1.4=1.65, \mathrm{P}=.211, \mathrm{t} 1.5=0.89, \mathrm{P}=.457, \mathrm{t} 1.6=0.81, \mathrm{P}=.438, \mathrm{t} 2=0.94$, $\mathrm{P}=.553)$.

Table 5. Analysis of students satisfied survey

\begin{tabular}{lll}
\hline Question & Mean & level of satisfaction \\
\hline Factors And Physical Environment & & \\
1. The teacher annunciates about the method of teaching. & 4.61 & very good \\
2. The teacher annunciates about the measurement and evaluation. & 4.43 & good \\
3. The teacher enters the classroom punctually. & 4.40 & good \\
4. The teacher dress properly decorum. & 4.38 & good \\
5. The teacher has instructional media. & 4.27 & good \\
Total & 4.42 & good \\
Process passes on Knowledge & & \\
6. The ability teaches of teacher. & 4.55 & very good \\
7. Teaching intentionally consider of ability students. & 4.35 & good \\
8. Teacher has knowledge and efficiency. & 4.58 & very good \\
9. Teacher infiltrate morality when teacher teach. & 4.35 & good \\
10. Teacher teaches content easily understood. & 4.47 & good \\
11. Instructional media have interestedness. & 4.15 & good \\
12. Process of instruction have variety and reinforce learning of stu- & 4.10 & good \\
dents. & 4.36 & good \\
Total & & \\
The result & 4.30 & good \\
13. The students receive knowledge and usefulness from studying. & 4.22 & good \\
14. The students have satisfied in instructional. & &
\end{tabular}


15. The students received usefulness and used daily life.

16. The students more realize health literacy of National Health Recommendations.

Total

Sum Total
4.57 very good

$4.45 \operatorname{good}$

4.39 good

4.39 good

In Table 5, the result showed survey satisfaction those who participated in health promotion literacy program those who satisfied good level $(=4.39)$. When considering each sub-topic, the results show that the students who had satisfaction in factors and physical environment that good level $(=4.42)$ who satisfied most the teacher annunciates about the method of teaching that very good level $(=4.61)$. Second, the students who had satisfaction in the result that good level $(=4.39)$ because those who received usefulness and used daily life. Finally, the students who had satisfaction in process passes on knowledge of teacher that good level $(=4.39)$ because teacher has knowledge and efficiency.

The effect of health literacy promotion program on health behaviors according to the National Health Recommendations of junior high school students. It can be described that as students participated in health literacy promotion programs, there was a different comparison result obtained from the post-test questionnaire with the result from pre-test questionnaire by using paired t-test which has equal total scores. The first sample group has an average score of pre-tests at a fair level $\left(\mathrm{x}^{-}=80.66,45.23\right)$ and an average score of posttests at a very good level $(\mathrm{x}=101.80,64.47)$. The second sample group has an average score of pre-tests at a fair level $\left(\mathrm{x}^{-}=78.73,51.63\right)$ and an average score of post-tests at a very good level $\left(\mathrm{x}^{-}=106.23,66.90\right)$. From the standard score table $t$, there was statistically significant at the 0.05 level and shown that health literacy promotion program of health behaviors according to the National Health Recommendations can positively affect students' learning outcomes. (Siritiwakron \& Julladit, 2020) which is consistent with the research of Songsaigath et al. (2020) and Worayan et al. (2020) that examined the effect of health educational program on knowledge and health behaviors on the tenth National Health Recommendations of elementary students and it was found that after participating the program, the mean scores of knowledges and behavior on pretest and post-test were significantly different at $p=.001$ and .017 respectively. As the comparison of posttest and pre-test differences between the first sample group and the second sample group by using independent t-test. It was explained that both sample groups have a mean score of pre-tests on health literacy at fair level ( $\left.\mathrm{x}^{-}=80.66,78.73\right)$, in term of health behaviors according to the National Health Recommendations was at a fair level $\left(\mathrm{x}^{-}=45.23,51.63\right)$ and has an average score of post-tests on health literacy was at a very good level $\left(\mathrm{x}^{-}=101.80,106.23\right)$. In term of health behaviors according to the National Health Recommendations was at a very good level $\left(\mathrm{x}^{-}=64.47,66.90\right)$ from the standard score table $t$, there was no statistically significant difference at the 0.05 level. It is shown that students who come from different schools totally have similar knowledge, perceptions and behaviors which is consistent with the research work of Sriboonyaruk \& Imarom (2021) and found that from a study on health care behaviors comparison of students studying at different schools, different sexes, different grades. There were no significant differences in the overall level of health self-care behaviors according to the National Health Recommendations. When considering each aspect, it was found that health behavior modification of oneself with communicating skill and health information exchange (Punnawit \& Thonthep, 2020). There was a statistically significant difference at the 0.05 level, probably because the students had different thought, feelings, and attitudes towards health care, which is consistent with the research by Srijun, et al. (2019) that examined the factors related to health care behaviors according to the tenth National Health Recommendations of adolescents in Phayao Province. When students enrolled in the health literacy promotion program on health behaviors according to the National Health Recommendations, they had a high level of overall satisfaction with learning management because there are a variety of activities, opportunity to interact in groups, clear transmission process, and application in daily life which is consistent with the research by Phakkunphan (2018) that studied on the academic achievement and motivation in learning mathematics of students in Matthayomsuksa 2 who received a gamification learning management with collaborative learning (Barata et al., 2013; Prompachad, 2013; Poondej \& Lerdpornkulrat, 2016).

\section{CONCLUSION}

This study has shown that this health literacy promotion program on health behaviors according to the National Health Recommendations can positively affects student learning outcomes. They 
will be able to develop health care skills for themselves and others around them. It also encourages students to realize and appreciate how to have good health for their bodies, cheerful mood, good interaction with their families, common interest thought, application in daily life, health behaviors modification to be more qualified and application of this program to students who are studying from different schools.

\section{REFERENCES}

Barata, G., Gama, S., Jorge, J., Gon, D. \& Alves. 2013. Improving Participation and Learning with Gamification. Paper presented at the Proceedings of the First International Conference on Gameful Design, Research, and Applications, Toronto, Ontario, Canada. https://dl.acm.org/ doi/10.1145/2583008.2583010

Division of Health Education Department of Health Service Support Ministry of Health. 2019. Health education program to health literacy according to the National Health Act. available at: $\quad$ http://hed.go.th/linkHed/374

Division of Health Education Department of Health Service Support Ministry of Health. 2021. A series of learning activities to health literacy and health behaviors for school age groups and working age groups. available at: http://www.hed.go.th/linkHed/427

Kaeodumkoeng, K. 2018. Health Literacy: Access, Understand and Apply (1st edition). Bangkok: Amarin Printing and Publishing.

Kapp, K.M. 2012. The Gamification of Learning and Instruction: Game-Based Methods and Strategies for Training and Education: John Wley \& Sons. https://www.wiley.com/en-us/The+Ga mification+of+Learning+and+Instruction $\% 3 \mathrm{~A}+$ Game+based+Methods+and+Strategies+for +Training+and+Education-p-9781118096345

National Health Development Plan Administration Committee Ministry of Health. 2016. National Health Development Plan No. 12 (2017-2021). available at: http://wops.moph.go.th/ops/oic/ data/20161115144754_1_.pdf

Orem, D.E. 1985. Nursing Concept of Practice (3rd ed). New York: McGrow Hill.

Park A, Eckert TL, Zaso MJ, et al. 2017. Associations between Health Literacy and Health Behaviors among Urban High Schoolers. J Sch Health, 87(12): 885-893. https://pubmed.ncbi.nlm.nih. gov/29096408/

Phakkhunphan, W. 2018. Proceeding of the National Conference Innovation for Learning and Inventions ( $p p$. 206-215), Pathum Thani: Rajamangala University of Technology.

Poondej, Ch., \& Lerdpornkulrat. 2016. Learning Management with the Gamification Concept. Journal of Education Naresuan University. 18 (3): 331-339. https://so06.tci-thaijo.org/index.php/ edujournal_nu/article/view/104390

Prompachad S. 2013. Health Behaviors According to National Health Commandments of Prathom Suksa 4-6 Students at Banrantadpom School in Songpeenong Subdistrict, Tha Sae District, Chumphon Province. Veridian E-Journal, 6 (1): 881-893. https://he02.tci-thaijo.org/index.php/ Veridian-E-Journal/article/view/40465/33397

Punnawit, Ch., \& Thongthep, S. 2020. Health Literacy and Health Behaviors According to National Health Recommendations among Students Aged 10-14 Year Oldin Chaloem Phra Kiat District, Nakhon Si Thammarat Province. Journal of Allied Health Sciences Suan Sunandha Rajabhat University, 5 (1): 26-36. http://journal.ssru.ac.th/index.php/jahs/issue/view/49

Silva, M.J. \& Santos, P. 2021. The Impact of Health Literacy on Knowledge and Attitudes towards Preventive Strategies against Covid-19: A Cross Sectional Study. International Journal of Environmental Research and Public Health, 18 (10): 5421. https://doi.org/10.3390/ijerph18105421

Siritiwakron C. \& Julladit A. 2020. Health Behaviors According to National Health Commandments of Grade 7

Students at Sirirattanathorn School. Suan Sunandha Academic \& Reseach Review, 14 (2): 91-98. http://journal.ssru.ac.th/index.php/ssajournal/article/view/871

Sriboonyaruk, T. \& Imarom, V. 2020. Relationships between Knowledge and Self-care Behaviors based on the National Health Recommendations of Students under the Secondary Education Service Area Office 10 Samut Sakhon District, Samut Sakhon Province. Sikkha Journal of Education, 8 (1): 67-75. http://ithesis-ir.su.ac.th/dspace/handle/123456789/2743

Srijun, P., Charoendee, S., Chaitiang, N., Juwa, S., Kadkhaow, A. \& Sangsrichan, C. 2019. Factors Re- 
lated to Health Care Behaviors based on 10 National Health Recommendation among Teenager in Phayao Province. Public Health and Laws Journal, 5 (1): 31-40. https://doi. org/10.1016/123456

Songsaigath, S., Kosuwin, R., Srimee, P., Chanthamud, S., Yungyun, K. \& Twatchmetanant, K. 2021. The Effect of Health Educational Program on Knowledge and Health Behaviors of Ten National Health Recommendations among Primary School Students in Wat Chiao Osot Community School, Nakhon Nayok Province. Journal of Health and Nursing Research, 37 (1): 206-216. https://he01.tci-thaijo.org/index.php/bcnbangkok/article/ view/249295

Worayan O., Krungkraipeth N. \& Junprasert S. 2020. Effect of self-Efficacy Enhancement Program on Primary School Students'Health Outcomes and Behaviors in Accordance with National Health Recommendation. Journal of Health and Nursing Research. 36(1):123-135 